\title{
Youth, faith, climate change and environmental consciousness: A case for sustainable development
}

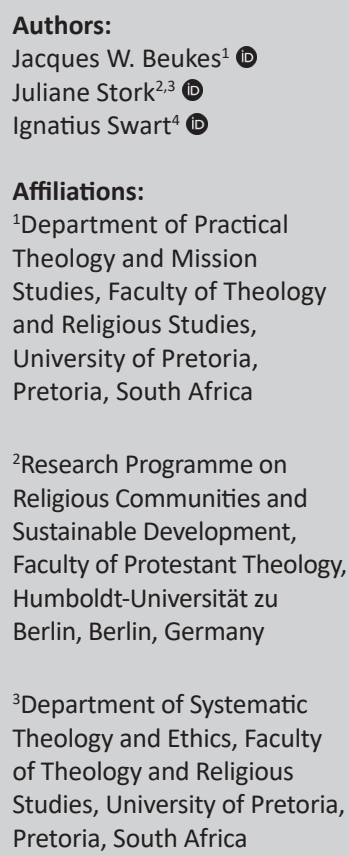

Corresponding author: Jacques Beukes, jacques.beukes@up.ac.za

How to cite this article: Beukes, J.W., Stork, J. \& Swart, I., 2021, 'Youth, faith, climate change and environmental consciousness: A case for sustainable development', HTS Teologiese Studies/ Theological Studies 77(2), a7085. https://doi.org/ 10.4102/hts.v77i2.7085

\section{Copyright:}

(C) 2021. The Authors.

Licensee: AOSIS. This work is licensed under the

Creative Commons

Attribution License.

\section{Read online:}

Climate change and environmental destruction are amongst the most threatening challenges to humanity and sustainable development globally. Young people find themselves right in the centre of debates about ecological (in)justice, environmental awareness, and climate change discourses and practices. Youth movements worldwide, such as 'Extinction Rebellion' and 'Fridays for Future,' demonstrate that youths are concerned about environmental problems and ready to become active in climate movements. Their willingness to act on their own behalf makes them one of the most important and interesting groups to learn more about in relation to the challenge of building a deeper awareness of environmental issues. Exploring and learning how youths are engaged with these discourses, how they contribute to a wider social consciousness of environmental issues and how such awareness is affected by different factors, such as the role and the contribution of young people's own religious beliefs, are, therefore, of paramount importance.

Through the present collection of articles, which constitutes the outcome of a South AfricanGerman partnership, ${ }^{1}$ we have made a concerted attempt to start exploring the four-fold nexus between youth, faith, climate change and environmental consciousness. Our working thesis is that this collective concern constitutes a vastly under-researched focus in the fields of practical theology and religious studies. This special collection invited researchers from Africa and Europe to collaborate across different fields to address this research gap and contribute to exploring the four-fold nexus. We believe that interdisciplinary, multidisciplinary and interfaith dialogue is crucially needed at the intersection of theological and religious studies, development studies, the social sciences and humanities more broadly speaking, and the natural sciences. To this end, as a modest beginning to an ongoing collaboration, we have succeeded in attracting a significant number of researchers to contribute to this research study. In total, 10 articles are presented. In terms of the thematic focus, they are compelling for their theoretical, conceptual and methodological insights (especially the contributions by Beukes, Van der Westhuizen, and Weber and Weber); exploration and application of particular theological approaches (especially the contributions by Baron and Knoetze); contextual and case study relevance (especially the contributions by Aziz, Kroeck, Maseno and Mamati, Willms, and Mamati and Maseno); and scope of denominational and interfaith focus (especially the contributions by Kroeck, Maseno and Mamati, Willms, and Mamati and Maseno).
1.We will continue this partnership in the next four years $(2022-2025)$ under the project consortium 'South African - German Research Hub on Religion and Sustainability' (SAGRaS), which will be funded by the National Research Foundation (NRF) and German Federal Ministry of Education and Research (BMBF) and forms part of the South African-German Collaborative Research Programme (SAGCORE) on 'The Interface between Global Change and Social Sciences - post-COVID-19'.

Note: Special Collection: Youth, Faith, Climate Change and Environmental Consciousness: A Case for Sustainable Development, sub-edited by Jacques Beukes (University of Pretoria), Juliane Stork (Humboldt University, Berlin) and Ignatius Swart (University of the Western Cape). 